\title{
Prolonged time from intubation to cannulation in VV-ECMO for COVID-19: does it really matter?
}

\author{
Pierre-Yves Olivier ${ }^{1 *}$ (D) Gregoire Ottavy ${ }^{2}$, Jerome Hoff ${ }^{3}$, Johann Auchabie ${ }^{4}$, Cedric Darreau ${ }^{5}$ and Marc Pierrot ${ }^{1}$
}

Extrapolating data from H1N1 influenza pandemic, ELSO guidelines for VV-ECMO [1], consider a duration of mechanical ventilation exceeding 7 days as a relative major contraindication for VV-ECMO in patients with COVID-19-associated ADRS (CARDS).

The previously published cohorts of CADRS treated with VV-ECMO report a $65 \%$ survival rate with a strict patients' selection [2]. We report the results of a retrospective cohort from three French ECMO centers, which did not apply such restrictive policy in these patients.

Data are presented as median value (interquartile range) or number (percentage). Comparisons were made using Wilcoxon-Mann-Whitney or Fisher's exact tests as appropriate. Logistic models were used to evaluate associations after adjustment on covariates. According to French regulation, the study was approved by the Angers University Hospital ethics committee and information letters were sent to the patients.

Fifty-six patients (49 men, 7 women) aged 24 to 71 years were treated with ECMO from March 2020 to June 2021 (Table 1) after 0-36 days of mechanical ventilation. Initiation of ECMO was decided collegially, based on EOLIA trial criteria, namely refractory hypoxemia or hypercapnic acidosis $\left(\mathrm{PaO}_{2}<80 \mathrm{mmHg}\right.$ for $6 \mathrm{~h}$ or $<60 \mathrm{mmHg}$ for $3 \mathrm{~h}$ or $\mathrm{pH}<7.25$ for $3 \mathrm{~h}$, despite appropriate ventilatory settings and prone positioning) [3], and depending on age, comorbidity and clinical history.

\footnotetext{
*Correspondence: pierreyves.olivier@chu-angers.fr

${ }^{1}$ Medical ICU, Vent'Lab, University Hospital of Angers, Angers, France

Full list of author information is available at the end of the article
}

The patients received VV-ECMO support for 17.5 (1031.2 ) days and $27 / 56$ (48\%) discharged hospital. Patients' survival according to age, SOFA score at cannulation and duration of mechanical ventilation before ECMO are reported in Fig. 1. Patients' age was associated with mortality $(p=0.014)$. There was no significant association between the duration of mechanical ventilation before VV-ECMO and the mortality (mortality of $53 \%$ vs. $50 \%$ in patients cannulated before or after 7 days of mechanical ventilation, respectively, $p>0.999$ ), even after adjustment on age and SOFA score at cannulation (adjusted $\mathrm{OR}=0.76$ [0.21-2.66], $p=0.673$ ).

The mortality observed in our cohort was higher than previously reported in patients treated with VV-ECMO during the first COVID-19 pandemic wave [2], including younger patients (median age of 49 vs. 57 years), but was similar to the one reported in larger cohorts of the second and third waves [4]. Our results are consistent with the data showing a strong association between age and mortality in COVID-19 patients [5].

The relative contraindication for VV-ECMO in patients mechanically ventilated for more than 7 days in ELSO guidelines remains questionable. It is mainly based on ELSO registry data referring to patients cannulated before 2012, particularly during the H1N1 influenza pandemic, reporting a strong correlation between mortality and duration of mechanical ventilation before cannulation [6], but has never been investigated in a prospective trial.

In the COVID-19 context with a very high pressure on available resources, most of the ECMO centers seem to have strongly limited their indications of late

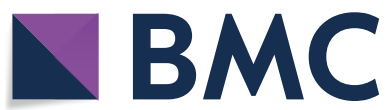

(C) The Author(s) 2021. Open Access This article is licensed under a Creative Commons Attribution 4.0 International License, which permits use, sharing, adaptation, distribution and reproduction in any medium or format, as long as you give appropriate credit to the original author(s) and the source, provide a link to the Creative Commons licence, and indicate if changes were made. The images or other third party material in this article are included in the article's Creative Commons licence, unless indicated otherwise in a credit line to the material. If material is not included in the article's Creative Commons licence and your intended use is not permitted by statutory regulation or exceeds the permitted use, you will need to obtain permission directly from the copyright holder. To view a copy of this licence, visit http://creativecommons.org/licenses/by/4.0/. The Creative Commons Public Domain Dedication waiver (http://creativeco mmons.org/publicdomain/zero/1.0/) applies to the data made available in this article, unless otherwise stated in a credit line to the data. 
Table 1 Initial characteristics, respiratory care before VV-ECMO cannulation and evolution for COVID-19-associated ADRS

\begin{tabular}{|c|c|c|c|c|}
\hline & $\begin{array}{l}\text { Total cohort } \\
n=56\end{array}$ & $\begin{array}{l}\text { ECMO survivors } \\
n=27\end{array}$ & $\begin{array}{l}\text { ECMO non-survivors } \\
n=29\end{array}$ & $p$ \\
\hline \multicolumn{5}{|l|}{ General characteristics } \\
\hline Age (Years) & $57(51-65)$ & $56(50-60)$ & $60(55-66)$ & 0.036 \\
\hline Male gender & $49(88)$ & $23(85)$ & $26(90)$ & 0.7 \\
\hline BMI $\left(\mathrm{kg} / \mathrm{m}^{2}\right)$ & $30(27-34)$ & $33(29-36)$ & $28(27-34)$ & 0.09 \\
\hline \multicolumn{5}{|l|}{ Comorbidities } \\
\hline Hypertension & $29(52)$ & $15(56)$ & $14(48)$ & 0.61 \\
\hline Diabetes & $16(29)$ & $6(22)$ & $10(35)$ & 0.38 \\
\hline \multicolumn{5}{|l|}{ Pre-ECMO care } \\
\hline Time from first symptom to ECMO (days) & $18(10-22)$ & $18(10-20)$ & $18(13-25)$ & 0.22 \\
\hline Time from intubation to ECMO (days) & $6(4-13)$ & $6(1-13)$ & $6(4-10)$ & 0.41 \\
\hline Prone position & $56(100)$ & - & - & - \\
\hline Neuromuscular blockers & $56(100)$ & - & - & - \\
\hline \multicolumn{5}{|l|}{ Ventilation parameters at cannulation time } \\
\hline Tidal volume (mL/kg of PBW) & $5.9(5.5-6.1)$ & $5.7(5.4-6)$ & $5.9(5.5-6.1)$ & 0.55 \\
\hline PEEP $(\mathrm{cmH} 2 \mathrm{O})$ & $10(6-14)$ & $10(7-14)$ & $10(5-14)$ & 0.73 \\
\hline P Plat $(\mathrm{cm} \mathrm{H} 2 \mathrm{O})$ & $31(30-34)$ & $31(30-35)$ & $31(30-32)$ & 0.80 \\
\hline Compliance of RS (mL/cm H2O) & $20(15-23)$ & $20(14-24)$ & $19(15-24)$ & 0.87 \\
\hline \multicolumn{5}{|l|}{ Gazometric parameters at cannulation time } \\
\hline $\mathrm{pH}$ & $7.29(7.23-7.36)$ & $7.30(7.25-7.37)$ & $7.28(7.23-7.36)$ & $>0.99$ \\
\hline $\mathrm{PaO} 2 / \mathrm{FiO} 2(\mathrm{~mm} \mathrm{Hg})$ & $62(53-74)$ & $60(53-67)$ & $62(55-75)$ & 0.38 \\
\hline $\mathrm{PaCO} 2(\mathrm{~mm} \mathrm{Hg})$ & $63(52-73)$ & $64(55-70)$ & $62(50-75)$ & $>0.99$ \\
\hline \multicolumn{5}{|l|}{ SOFA score at cannulation time } \\
\hline Total SOFA score & $7(4-8)$ & $7(4-8)$ & $7(4-10)$ & 0.75 \\
\hline SOFA score excluding respiratory item & $3(0-4)$ & $3(0-4)$ & $3(1-6)$ & 0.49 \\
\hline \multicolumn{5}{|l|}{ General evolution } \\
\hline ECMO duration (days) & $18(10-31)$ & $18(8-31)$ & $17(12-32)$ & 0.85 \\
\hline ICU duration (days) & $46(28-60)$ & $59(47-75)$ & $31(23-43)$ & $<0.01$ \\
\hline ECMO complications & $29(52)$ & - & - & - \\
\hline Bleeding & $48(86)$ & $20(74)$ & $28(97)$ & 0.023 \\
\hline Infections & $37(66)$ & $18(67)$ & $19(66)$ & $>0.99$ \\
\hline Hemolysis & $19(34)$ & $10(37)$ & $9(31)$ & 0.78 \\
\hline \multicolumn{5}{|l|}{ Death causes n (\% of non-survivors) } \\
\hline Bleeding & - & - & $12(41)$ & \\
\hline Sepsis & - & - & $10(35)$ & \\
\hline End-of-life decision & - & - & $4(14)$ & \\
\hline
\end{tabular}

Bold highlighted significant differences between the two groups $(p<0.05)$

All data are presented as median (interquartile range) or number (percentage). Survivors and non-survivors are determined considering hospital mortality

cannulation. To the best of our knowledge, our cohort is the first specific report of late cannulation experience in this indication and our results suggest that it is feasible and may have benefit some patients (69\% survival rate in patients under 60 years of age cannulated after 7 days of mechanical ventilation in our cohort).

Our study has several limitations. It is a retrospective cohort with a limited number of patients, and some subjective criteria may have been considered in decisions of VV-ECMO initiation even if a predefined common protocol was used.

In conclusion, a late initiation of VV-ECMO for CARDS was not associated with an increased mortality in our cohort. The criterion of duration of mechanical ventilation for the decision of VV-ECMO initiation in this indication should be carefully considered. 


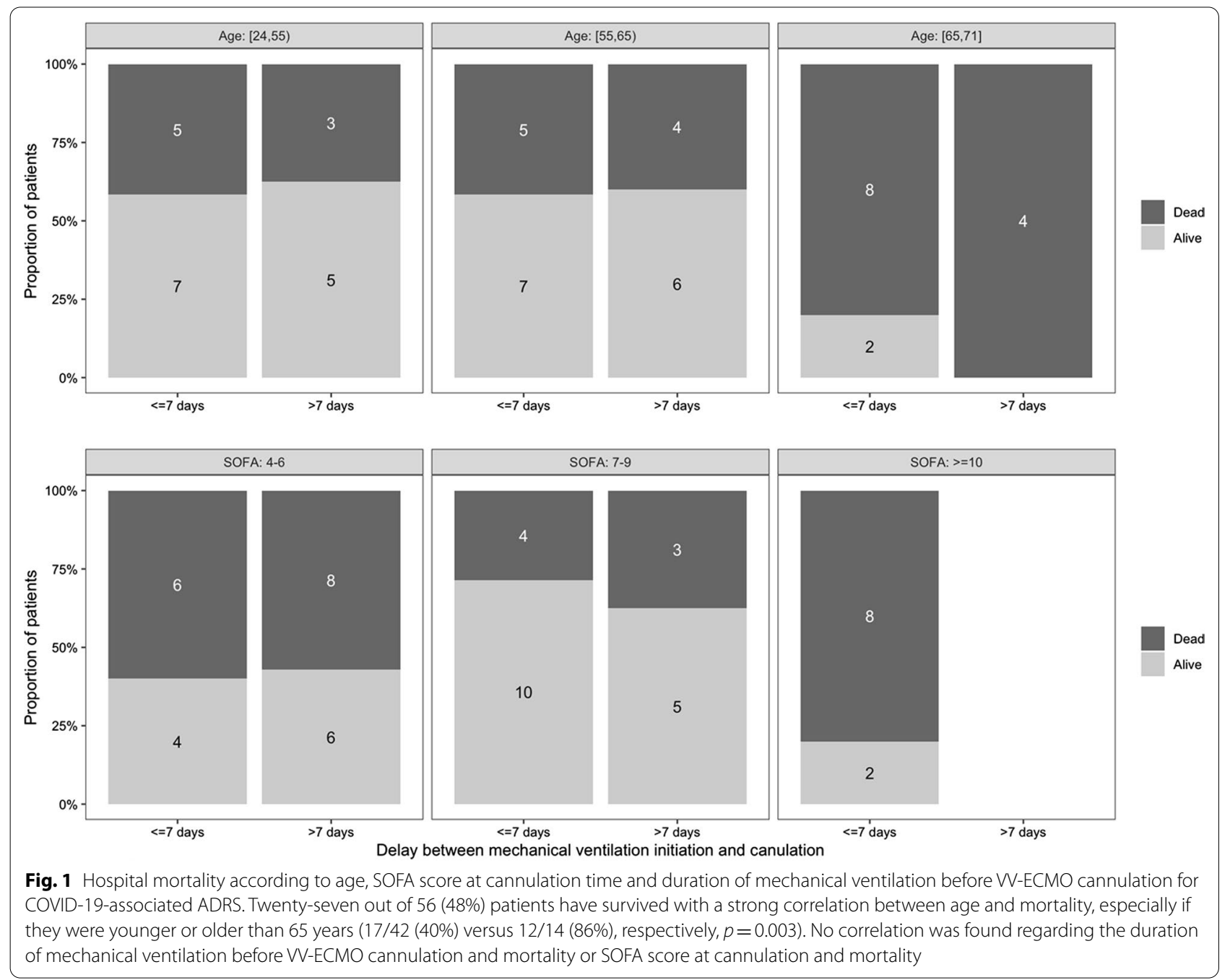

\section{Acknowledgements}

Not applicable.

\section{Authors' contributions}

P-YO contributed to data collection, statistical analysis, and manuscript writing. $\mathrm{GO}, J \mathrm{H}, \mathrm{JA}$ and $\mathrm{CD}$ collected the data. MP helped in manuscript co-writing. All authors read and approved the final manuscript.

\section{Funding}

No specific fund was used for this study.

\section{Availability of data and materials}

The datasets used and/or analyzed during the current study are available from the corresponding author on reasonable request.

\section{Declarations}

\section{Ethics approval and consent to participate}

The study was approved by the Angers University Hospital ethics committee. Patients consent was waived because of the retrospective nature of the study according to French regulation.

\section{Consent to publication}

Not applicable.

\section{Competing interests}

The authors declare that they have no competing interests.

\section{Author details}

${ }^{1}$ Medical ICU, Vent'Lab, University Hospital of Angers, Angers, France. ${ }^{2}$ Centre Hospitalier Universitaire de Nantes, Département de Médecine Intensive Réanimation, Université de Nantes, Nantes, France. ${ }^{3}$ Département de Médecine Intensive Réanimation, Centre Hospitalier de Saint Nazaire, Saint Nazaire, France. ${ }^{4}$ Centre Hospitalier de Cholet, Réanimation et Unité de Surveillance Continue, Cholet, France. ${ }^{5}$ Centre Hospitalier du Mans, Réanimation Médico Chirurgicale Et Unité de Surveillance Continue, Le Mans, France.

Received: 8 October 2021 Accepted: 21 October 2021

Published online: 10 November 2021

\section{References}

1. Badulak J, Velia Antonini M, Stead CM, Shekerdemian L, Raman L, Paden ML, Agerstrand C, et al. ECMO for COVID-19: updated 2021 guidelines from the extracorporeal life support organization (ELSO). ASAIO J. 2021. https://doi.org/10.1097/MAT.00000000000001422.

2. Schmidt M, Hajage D, Lebreton G, Monsel A, Voiriot G, Levy D, Baron E, et al. Extracorporeal membrane oxygenation for severe acute respiratory distress syndrome associated with COVID-19: a retrospective cohort 
study. Lancet Respir Med. 2020;8(11):1121-31. https://doi.org/10.1016/ S2213-2600(20)30328-3.

3. Combes A, Hajage D, Capellier G, Demoule A, Lavoué A, Guervilly C, Da Silva D, et al. Extracorporeal membrane oxygenation for severe acute respiratory distress syndrome. N Engl J Med. 2018;378(21):1965-75. https:// doi.org/10.1056/NEJMoa1800385.

4. https://www.elso.org/Registry/FullCOVID19RegistryDashboard.aspx

5. Schmidt M. Clinical characteristics and day- 90 outcomes of 4244 critically ill adults with COVID-19: a prospective cohort study. Intensive Care Med. 2021;47(1):60-73. https://doi.org/10.1007/s00134-020-06294-x.

6. Schmidt M, Bailey M, Sheldrake J, Hodgson C, Aubron C, Rycus PT, Scheinkestel $C$, et al. Predicting survival after extracorporeal membrane oxygenation for severe acute respiratory failure. The respiratory extracorporeal membrane oxygenation survival prediction (RESP) score. Am J Respir Crit Care Med 2014;189(11): 1374-82. https://doi.org/10.1164/ rccm.201311-20230C

\section{Publisher's Note}

Springer Nature remains neutral with regard to jurisdictional claims in published maps and institutional affiliations.
Ready to submit your research? Choose BMC and benefit from:

- fast, convenient online submission

- thorough peer review by experienced researchers in your field

- rapid publication on acceptance

- support for research data, including large and complex data types

- gold Open Access which fosters wider collaboration and increased citations

- maximum visibility for your research: over $100 \mathrm{M}$ website views per year

At BMC, research is always in progress.

Learn more biomedcentral.com/submissions 